\title{
A Singular Thought
}

\section{Dear Sir,}

I hope you won't regard it as a hyperbolic cheek

If I make to passing mention to both Latin and to Greek.

Scientists may find that this is almost extra-mural

But I'd like to make an issue of a quaint and spreading plural.

We all agree a "pancreas" is singularly single,

But a plural's now appearing that would make a Greek's ears tingle:

"Pancreata" seem to have a Latin-sort of ending

(Though the Greeks declined indulgently with all the rules a-bending)

For the common plural form of "ass" should clearly be an "ah" -

A single "pancreas" and ten thousand "pancrea"!

Now acceptance of this dictum is unlikely to be wide

For as animals of habit we prefer the often-tried,

But let us not be ridiculed as ignoramus-asses
By writing down the ghastly form of "many pancreases". Though if "hair" and "grass" and "sheep" can serve for many and for one,

"Pancreas" might do as well for single and for some.

As a sombre thought to end with, I might raise the further spectre

Of what the future holds: for we will very soon expect a

Young aspiring doc to manage what would be the final feat

Of dissecting up a pancreas to find a diabete!

Dr. D. R. Matthews

Diabetes Research Laboratories

Radcliffe Infirmary

Oxford

UK

\section{Book Reviews}

M. Brownlee (Ed): Handbook of Diabetes Mellitus. Vol.1: Etiology/ Hormone Physiology. John Wiley \& Sons, Chichester, 1981. Hardback, 366 pages. $£ 30.00$ (US $\$ 84.00$ ) [whole 5 volumes: $£ 95.00$; US $\$ 275.00]$

This is the first of a five volume publication under the direction of a single editor. To judge from the titles the bias is heavily towards underlying mechanisms rather than clinical aspects of diabetes. Thus volume 5 is entitled Current and future therapies but the others are: 1. Aetiology and hormone physiology. 2. Islet cell function and insulin action. 3. Intermediary metabolism and its regulation. 4. Biochemical pathology. This seems an uneven balance if the aim of the handbook (totalling about 2000 pages) is to review the whole subject of diabetes including its multifarious clinical problems. If on the other hand, the aim is essentially to provide a review of the science, as distinct from the art, of diabetes it runs a risk that in this format it will not be sufficiently up-to-date.

That risk this volume does not avoid. Thus the first chapter by Rotter and Rimoin on genetics is, as you would expect from them, admirable, but it is already well out-of-date. They list 469 references but only a handful are as recent as 1979 and much has happened since then. The short chapter on viruses is similarly dated, as are the others.

This may be an inevitable drawback of so compendious a survey; if so, it leads one to doubt its value. Unless review articles appear within a matter of 6-12 months I doubt if they are worth writing. Perhaps in a slow-moving field this does not apply, but so much is happening in diabetes, especially in its scientific aspects, that it certainly does apply to our subject. One cause of the delay may be the immense scholarship of the papers - they are studded with references (sometimes listed in order of quoting, sometimes in alphabetical order). Almost one-third of the book is occupied by lists of references. I wonder if such a lavish display of reading is essential. Could not some facts be allowed to stand on their own or be assumed to be part of the common knowledge? I raise these difficulties in the hope that editors of multi-author books will decide how they propose to surmount them before embarking on what is an immense task for themselves and their contributors. If they cannot, I advise abstinence!

D. A. Pyke (London)
Handbook of Diabetes Mellitus. Vol.2: Islet Cell Function/Insulin Action. John Wiley \& Sons, Chichester, 1981. Hardback, 225 pages. $£ 17.00$ (US $\$ 47.60$ ) [whole 5 volumes: $£ 95.00$; US $\$ 275.00$ ]

Research on the mechanisms by which glucose stimulates insulin secretion has many patterns of thought in common with research on the effects of insulin on its target cells. In both areas cell physiological variables such as inorganic ion fluxes, nucleotide metabolism, membrane electric events, enzyme activation and so forth play a central role. It is therefore logical that the second volume of the Handbook of Diabetes Mellitus (edited by Michael Brownlee) contains various chapters on the synthesis (Permutt), secretion (Malaisse et al.; Ostlund), binding (Olefsky and Ciaraldi), and regulatory effects (Czech; Jungas; Strom and Helderman) of insulin. Emphasis is on insulin action. As often when many experts contribute by summarizing their own special fields, the book is a charming blend of temperaments and attitudes to the task of reviewing. For example, in giving a fair amount of experimental detail, Permutt appears primarily to address the active laboratory man or woman. The paper by Malaisse et al. is a distilled product from a more voluminous and flocculent broth; the essence of stimulus recognition in the B cells comes through with a pleasant ease that should even tickle the nostrils of those who view the world from the study arm-chair rather than from the bench. Regardless of such differences in style, it seems to me that all chapters should make useful and rewarding reading for anyone who wants to update his or her knowledge of mechanisms central to the discussion, and hopefully to the understanding, of diabetes. Unfortunately, or perhaps fortunately, progress is sometimes so fast as to make impossible the production of a review truly up-to-date on every point. To the limited extent that this problem can be noticed in the present volume, it constitutes no serious shortcoming.

I.-B. Taljedal (Umea)

Handbook of Diabetes Mellitus. Vol.3: Intermediary Metabolism and Its Regulation. John Wiley \& Sons, Chichester, 1981. Hardback, 317 pages. $£ 23.00$ (US $\$ 64.00$ ) [whole 5 volumes: $£$ 95.00; US $\$ 275.00]$

Volume 3 has been reviewed previously - see Diabetologia 22: 138 . 